\title{
Different Grass Availabilities of Tropical Pasture on Performances and Carcasses of Lambs
}

\author{
N. da S. Heimbach, C. C. B. F. Ítavo, L. C. V. Ítavo, G. dos S. Difante, A. M. Dias, R. C. Brumatti, M. de \\ N. B. Gomes, C. D. Baur, G. J. de Moraes, M. C. M. da Costa, N. D. Kozerski, E. S. Leal, \& \\ A. L. C. Gurgel* \\ Faculty of Veterinary Medicine and Animal Science, Federal University of Mato Grosso do Sul, \\ Av. Senador Felinto Muller, 2443, CEP: 79070-900, Campo Grande, MS, Brazil \\ *Corresponding author: antonioleandro09@gmail.com \\ (12-02-2020; Revised 13-04-2020; Accepted 21-04-2020)
}

\begin{abstract}
This study aimed to identify the best green-leaf offerings of Urochloa brizantha cv. Marandu for pasture-finished lambs receiving protein-energy supplementation at the rate of $1.6 \%$ of their body weights (BW). The animals were assigned into four treatments, which consisted of varied green-leaf offerings, namely, 105, 90, 75, or $60 \mathrm{~g}$ of dry matter/ $\mathrm{kg}$ of body weight (BW). Sixty-eight contemporary Texel $\times$ mixed-breed lambs with an average initial BW of $22.6 \mathrm{~kg}$ were used over two years of experiment. The experiment was set up in a completely randomized design, the data were evaluated by analysis of variance and the means were compared by Tukey's test at the 0.05 significance level. There was no significant effect of year neither interaction of year with green-leaf offer. There were significant effects of leaf offer on dry matter intake (DMI) with behavior of positively linear $(p<0.05)$. There were significant effects of green-leaf offer on final BW and average daily gain, and lambs receiving of $75 \mathrm{~g} / \mathrm{kg}$ green-leaf offer showed the highest ADG $(179 \mathrm{~g} / \mathrm{d})$. There were no significant differences in the carcass, meat, and primal cuts between the groups of lambs receiving different herbage offerings. There were significant effects of leaf offer on slaughter weight, hot carcass weight, and subcutaneous fat thickness. Lambs receiving of $75 \mathrm{~g} / \mathrm{kg}$ leaf offer showed the highest SFT (5.8 $\mathrm{mm}$ ). Slaughter weight and hot carcass weight averaged $41.52 \mathrm{~kg}$ and $20.07 \mathrm{~kg}$, respectively. We recommend the treatment with leaves offer of $75 \mathrm{~g} / \mathrm{kg} \mathrm{BW}$ of Marandu pasture for the finishing of lambs supplemented at $1.6 \%$ of $\mathrm{BW}$.
\end{abstract}

Keywords: forage; grazing management; lambs; meat quality; Marandu pasture

\section{INTRODUCTION}

Urochloa spp. (Syn. Brachiaria) is the most widely used pasture in the Brazilian cerrado biome regions by virtue of its hardiness and little need for fertilizer (Euclides et al., 2019). In those regions, productions of animals are mostly finished on pasture. However, this type of system is known to possibly result in the reduced or worsened carcass composition (Euclides et al., 2018).

Proper nutrients utilization results in the increased gains per animal for the producer. Fat is the most variable tissue in the animal carcass, as can be influenced by the finishing system, diet, age, and sex. Fat is also a parameter of great importance since current consumer seeks meats with little fat content. In contrast, the carcass should have a minimum amount of this fat tissue to protect the muscle (meat) during refrigeration, thereby preventing the alterations of color, tenderness, and the other properties (Araújo Filho et al., 2010).

Meat is the main product of the sheep-production chain, and consumers have become increasingly de- manding when purchasing it. Some of the first aspects considered in choosing meat at the time of purchasing are color and smell, and later, flavor and tenderness (Osório et al., 2012). The nutritional quality of the diet supplied to the animal as well as management and slaughter procedures directly influence these characteristics.

In searching for alternatives strategy to improve the composition of carcass and meat of animals reared on pasture, the producers started to adopt a supplementation technique to improve the final animal product and make the system profitable, since the other options for finishing these animals would be the feedlot, which is a rather costly practice. However, the tropical pasturebased sheep finishing system is not yet well elucidated due to the lack of information and studies investigating the ideal herbage offering for sheep to optimize performance and final-product characteristics.

In this scenario, with a view to reduce costs but to maintain a good carcass and meat qualities, also to combine animal production with pasture quality, the present study was designed to examine the performance, carcass 
characteristics, and meat characteristics of lambs on Urochloa brizantha cv. Marandu pasture, under varied green-leaf offerings during the finishing stage.

\section{MATERIALS AND METHODS}

\section{Location, Animals, and Diets}

The experiment was conducted in the Sheep Farming Section at teaching farm (2026 $34.31^{\prime \prime} \mathrm{S}$ 54 o50'27.86"'W; $530.7 \mathrm{~m}$ altitude) belonging to the Faculty of Veterinary Medicine and Animal Science (FAMEZ) at UFMS, in Terenos - MS, Brazil. All experimental procedures were approved by the Ethics Committee on Animal Use at the Federal University of Mato Grosso do Sul (UFMS) (approval no. 481/2012).

Lambs, male, contemporary (60 days old on average) Texel $\times$ mixed breed, with an initial average weight of $22.6 \mathrm{~kg}$, from a pre-weaning system with slow feeding, were used for two consecutive years. The experimental period in the first year used 33 lambs and, in the second year, used 35 lambs. The animals were evaluated in the pasture after weaning at 60 days. All animals were slaughtered at six months of age (180 days old) by the end of the finishing stage.

After weighing at weaning, the 60 lambs were distributed with 12 animals per treatment. The treatments consisted of 4 offers of green leaves, namely: 105, 90, 75, and $60 \mathrm{~g} \mathrm{DM} / \mathrm{kg}$ of body weight. The supply of leaves was adjusted every 28 days, according to the variation of the animal weight and the pasture structure. The animals were weighed at the start of the experimental period and continued every 28 days to measure body weight gain and average daily gain. Body condition score (BCS) (Russel et al., 1969) and degree of anemia (Famacha ${ }^{\circledR}$ method) were also measured, and feces were collected every 28 days to count the number of eggs per gram of feces (EPG) (Gordon \& Whitlock, 1939).

Lambs were allocated to Urochloa brizantha cv. Marandu paddocks, where they grazed in a continuous grazing system with a variable stocking rate. Put-andtake animals were used whenever necessary to adjust herbage availability. All paddocks were equipped with a drinker and a trough for mineral supplementation, with unrestricted access. The supplement was provided at a rate of $1.6 \%$ of $\mathrm{BW}$. The supplement was formulated according to NRC (2007), based on corn, soybean meal, and minerals, to provide a daily weight gain of $150 \mathrm{~g} / \mathrm{d}$. Its nutritional composition included $909.0 \mathrm{~g} / \mathrm{kg}$ dry matter, $21 \%$ crude protein, and $3.1 \mathrm{Mcal} \mathrm{ME} / \mathrm{kg} \mathrm{DM}$. The same supplement was used for all treatments during the two years of experimental periods. For calculating supplement consumption per treatment, the value of daily head, and the consumption of supplements in the trial period was considered.

Herbage dry matter was measured every 28 days by the total sampling method, which consisted of harvesting six samples per paddock near the soil level (Euclides et al., 2019). The material was collected from within $0.5 \times 0.5 \mathrm{~m}$ metal frames that were cast over random points representative of each paddock. Areas near roads, spots of fecal accumulation, areas near troughs and drinkers, and areas with sparse herbage were avoided. After weighing and identification steps, composite samples per paddock were taken to the Laboratory of Applied Nutrition where the total aerial part was weighed, which was followed by a morphological separation to obtain the percentages of leaf, stem + sheath, and dead material (leaves and stems with progressive yellowing, darkening, and visible drying, characterizing the plant senescence stage). The amount of herbage available in each paddock (whose sizes were varied) and the percentage of the green leaf was calculated to adjust the stocking rate. Based on this calculation, it was possible to determine how many kilograms each paddock could carry according to each treatment $(60,75,90$, or $105 \mathrm{~g} / \mathrm{kg} \mathrm{BW})$.

\section{Chemical Analyses}

The concentrations of dry matter (DM), organic matter (OM; 100 - ash), crude protein (CP), and ether extract (EE) were determined by following AOAC (2000) methods 930.15, 932.05, 976.05, and 920.39, respectively. Neutral detergent fiber (NDF) and acid detergent fiber (ADF) contents were determined as proposed by Goering and Van Soest (1970), without using sulfite or heat-stable amylase (Table 1).

\section{Forage Sampling and Analysis}

Grazing simulation was performed by analyzing the way an animal was fed and the grazing site was monitored in order to obtain a representative sample of its natural and behavioral grazing habits. Monthly samples were collected manually without using scissors (Costa et al., 2019). Fecal sampling and grazing simulation were performed to obtain a sample composed of animal/treatment. After drying in an oven at $55^{\circ} \mathrm{C}$, the samples were processed in a sieve mill with sieves of 1 $\mathrm{mm}$ for subsequent laboratory analysis.

Table 1. Chemical compositions of leaf and stem in Urochloa brizantha CV. Marandu pasture

\begin{tabular}{|c|c|c|c|c|}
\hline \multirow{2}{*}{ Compound } & \multicolumn{4}{|c|}{ Green-leaf offering (kg DM/100 kg BW) } \\
\hline & 60 & 75 & 90 & 105 \\
\hline & \multicolumn{4}{|c|}{----------------Leaf---------------- } \\
\hline $\mathrm{DM}(\mathrm{g} / \mathrm{kg})$ & 390.0 & 405.5 & 396.8 & 412.4 \\
\hline $\mathrm{OM}$ (g/kg DM) & 909.8 & 908.9 & 906.2 & 914.5 \\
\hline CP (g/kg DM) & 103.0 & 107.9 & 108.0 & 149.8 \\
\hline NDF (g/kg DM) & 676.8 & 659.5 & 652.1 & 670.8 \\
\hline \multirow[t]{2}{*}{ ADF (g/kg DM) } & 375.7 & 368.9 & 367.3 & 380.7 \\
\hline & \multicolumn{4}{|c|}{-------------Stem------------- } \\
\hline $\mathrm{DM}(\mathrm{g} / \mathrm{kg})$ & 375.2 & 381.0 & 371.6 & 369.9 \\
\hline $\mathrm{OM}$ (g/kg DM) & 934.1 & 932.5 & 927.8 & 918.0 \\
\hline CP (g/kg DM) & 49.4 & 49.9 & 51.0 & 50.1 \\
\hline NDF (g/kg DM) & 791.4 & 760.0 & 787.5 & 766.5 \\
\hline $\mathrm{ADF}(\mathrm{g} / \mathrm{kg} \mathrm{DM})$ & 535.3 & 529.6 & 539.3 & 501.1 \\
\hline
\end{tabular}

Note: $\mathrm{DM}=$ dry matter; $\mathrm{OM}=$ organic matter; $\mathrm{CP}=$ crude protein; $\mathrm{NDF}=$ neutral detergent fiber; $\mathrm{ADF}=$ acid detergent fiber; $\mathrm{BW}=$ body weight. 
Internal indicator (iNDF) on forage and feces were determined using $0.5 \mathrm{~g}$ of samples packed in TNT bags (cut and sealed to a size of $5 \times 5 \mathrm{~cm}$ with the porosity of 100 microns), previously dried, weighed, and incubated for 144 hours to represent the indigestible portion of the food (Costa et al., 2019), in the in vitro incubator for degradability testing (MA443 Marconi®). Next, 1600 $\mathrm{mL}$ of buffer solution and $400 \mathrm{~mL}$ of rumen inoculum were added and $\mathrm{CO}_{2}$ was purged to maintain anaerobic conditions. After $144 \mathrm{~h}$ of inoculation, the bags were removed and washed in running water until fully bleached, dried, weighed then boiled for 1 hour in neutral detergent solution (Van Soest \& Robertson, 1985), washed with hot water $\left(80^{\circ} \mathrm{C}\right.$ for $\left.3 \times 10 \mathrm{~min}\right)$ and acetone (10 $\mathrm{min})$, dried, and weighed; this residue was considered as iNDF. Estimates of dry matter intake (DMI) was calculated, according to Lippke (2002).

\section{Slaughter}

The lambs were sent for slaughter at six months of age, after a solid-feed deprivation of $18 \mathrm{~h}$. Prior to slaughtering, their body condition scores (BCS) were determined by palpating the lumbar region and assigning scores of 1.00 to 5.00 (1.00 being the worst and 5.00 was the best) (Russel et al., 1969). Additionally, in vivo measurements of body length, heart girth, rump height, rump width, chest width, and height at the withers were also taken.

The lambs were slaughtered at an abattoir under inspection in Campo Grande - MS, Brazil. Lambs were stunned and then bled by sectioning their carotid arteries and jugular veins, following the techniques proposed in the Regulation of Industrial and Sanitary Inspection of Animal Products (RIISPOA, 1997). After the slaughtering and evisceration procedures, the carcasses were weighed (hot carcass weight - HCW) and moved to a cold room where they were kept over $24 \mathrm{~h}$, at $2^{\circ} \mathrm{C}$, hung by the Achilles tendons on appropriate hooks so that the tarsometatarsal joints were kept $17 \mathrm{~cm}$ apart. At the end of this period, cold carcass weight (CCW) was determined by calculating the percentage of chilling loss and the dressing percentage (ratio between cold carcass weight and slaughter weight).

\section{Carcass}

The colors of fat and muscle in the lamb carcasses were evaluated using a portable colorimeter (D65, 10음 viewing angle) operating in the CIELab system, in which $L^{*}$ represents the lightness spectrum in the fat/ muscle, $\mathrm{a}^{*}$ represents the color variation from green $(-)$ to red $(+)$, and $b^{*}$ defines the color variation from blue $(-)$ to yellow (+). The carcass $\mathrm{pH}$ was determined using a digital $\mathrm{pH}$ meter by inserting the electrode directly into the muscle. The color and $\mathrm{pH}$ evaluations were performed on the longissimus muscle in the region between the 12th and 13th ribs.

Internal and external carcass lengths, chest depth, and leg circumference were measured (Osório et al., 1996a; Osório et al., 1996b). Subsequently, the carcass was sectioned in two parts, and the left half was weighed and sub-divided into seven anatomical regions, which were weighed individually. The percentages of these regions relative to the whole carcass were determined, as follows: loin, leg, flank, neck, ribs (anatomical base at the eight last thoracic vertebrae, along with the upper half of the corresponding ribs), rack (region whose osseous base are the five dorsal vertebrae along with the upper half of the corresponding ribs), and shoulder (Trindade et al., 2018).

The longissimus muscle area was measured transversely between the 12th and 13th ribs using transparency. Loin-eye area (LEA) was determined using AUTOCAD ${ }^{\circledR}$ computer software. Subcutaneous fat thickness (SFT) was measured using a caliper ruler in the same longissimus section.

\section{Meat}

The samples were weighed and stored in a refrigerator for $24 \mathrm{~h}$ at $5^{\circ} \mathrm{C}$. After this period, they were weighed again to determine thawing losses by weight difference. Longissimus dorsi muscle samples of a $2.5-\mathrm{cm}$ thickness (frozen at $-20^{\circ} \mathrm{C}$ ) were extracted from each sample perpendicularly to the direction of the muscle fibers. Next, the muscle samples were cooked in an oven at $170^{\circ} \mathrm{C}$ until they reached an internal temperature of $71^{\circ} \mathrm{C}$ to determine cooking loss by difference. After the sample (longissimus muscle) was chilled and reached the temperature of $28^{\circ} \mathrm{C}$, four sub-samples of $1.23-\mathrm{cm}$ thickness were sectioned in the direction of the muscle fibers to determine the shear force, using a texture analyzer (TA. XTPlus was Texture Analyzer with a Warner-Bratzler Blade probe; Texture Expert Exponent software was Stable Micro Systems, Ltd, in Godalming Surrey UK. SMS). The result corresponded to the force required to cut each meat sample. Shear force value was calculated from all samples.

\section{Economic Analysis}

The economic data involved in all proposed treatments were recorded and organized as revenue obtained from the sale of lambs and nutritional costs with supplementation. Supplement costs were calculated per day, per animal, and per hectare $(30 \mathrm{~g} / \mathrm{d}$ of mineral supplement/animal), and revenues were calculated as US\$ 3.29 per kilogram of CCW of a slaughtered lamb.

\section{Statistical Analysis}

The experiment was set up as a completely randomized design with four levels of herbage offering, according to the following statistical model: $Y=m+$ Of $+Y+$ Of $\times Y+e$, where: $Y$ was the observed value of the evaluated variable; $\mathrm{m}$ was the overall constant; Of was the effect of green-leaf offering $(1,2,3$, and 4); $\mathrm{Y}$ was the different years $(1,2)$; Of $\times Y$ was the interaction effect between green-leaf offering and year; and e was the random error associated with each observation. The data were evaluated by analysis of variance and means were compared by Tukey's test at the 0.05 significance level. 


\section{RESULTS}

There was no significant effect of year neither interaction of year with the green-leaf offer on all parameters measured. The average herbage mass supplied was $4779.69 \mathrm{~kg} \mathrm{DM} / \mathrm{ha}$. This quantity consisted of $21.7 \%$ leaves, $27.7 \%$ stems, and $50.6 \%$ senescent material. There were significant effects of leaf offers on total and forage dry matter intakes (DMI) with positive linear behavior and negative linear behavior for DMI of supplement (Figure 1).

\section{Performance}

There were significant effects of leaf offer on final BW and average daily gain $(\mathrm{g} / \mathrm{d}$ ) of lambs (Table 2$)$. The in vivo pre-slaughter analysis of the lambs, which included final weight, body condition score, body length, chest girth, rump height, rump width, chest width, and height at the withers, revealed no significant effects of green-leaf offering in the finishing stage (Table 3).

\section{Carcass and Meat}

Herbage offering did not affect HCW, CCW, pH, internal length, external length, leg length, chest depth, leg circumference, LEA, or the color of muscle and fat $\left(L^{*}, a^{*}, b^{*}\right)$. The mean values for the respective variables were $20.07 \mathrm{~kg}, 18.55 \mathrm{~kg}, 5.82,62.02 \mathrm{~cm}, 91.67 \mathrm{~cm}, 38.73$ $\mathrm{cm}, 18.16 \mathrm{~cm}, 40.55 \mathrm{~cm}, 13.85 \mathrm{~cm}^{2}, 38.55,15.38,8.92$, $82.83,0.96$, and 9.01, respectively. However, there was

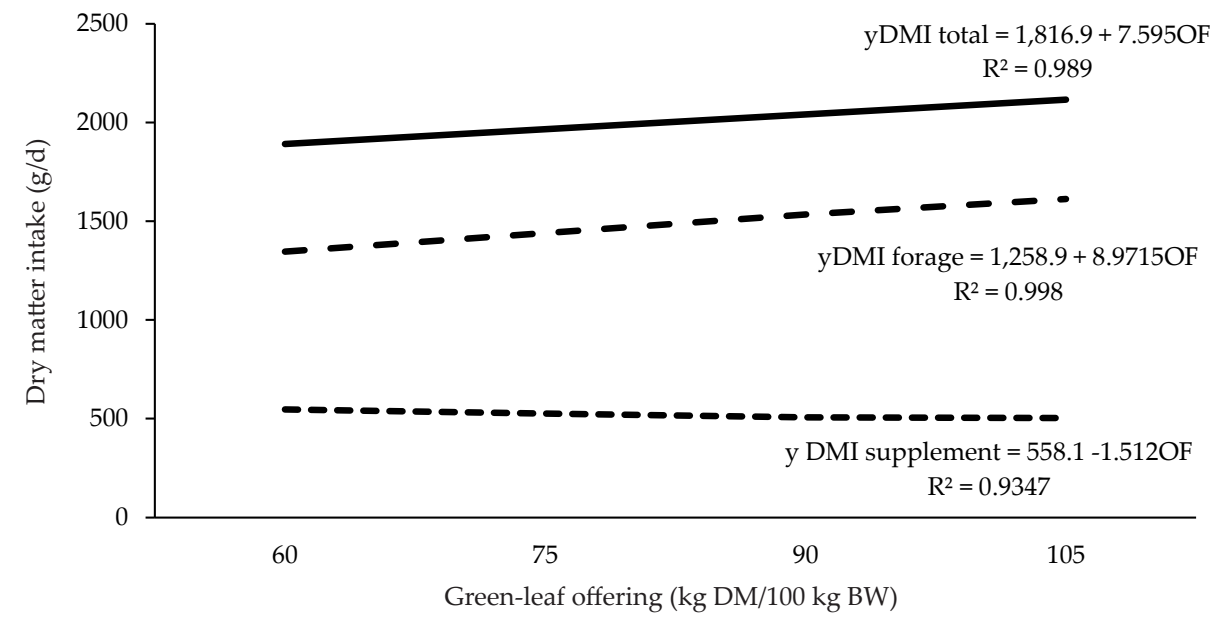

Figure 1. Dry matter intake (DMI) by lambs finished on Marandu pasture in function of green-leaf offering (OF). DMI supplement (_ - ), DMI forage (_ _ ), DMI total (__).

Table 2. Productive performance and nutrient intake of lambs finished on Marandu pasture slaughtered at 6 months old

\begin{tabular}{|c|c|c|c|c|c|c|}
\hline \multirow{2}{*}{ Performances } & \multicolumn{4}{|c|}{ Green-leaf offering (kg DM/100 kg BW) } & \multirow{2}{*}{ SEM } & \multirow{2}{*}{$\mathrm{p}$} \\
\hline & 60 & 75 & 90 & 105 & & \\
\hline Initial BW (kg) & 25.1 & 23.5 & 23.7 & 22.7 & 1.28 & 0.6879 \\
\hline Final BW (kg) & $43.2^{\mathrm{a}}$ & $42.2^{\mathrm{a}}$ & $39.6^{\mathrm{b}}$ & $40.1^{\mathrm{b}}$ & 1.64 & 0.0358 \\
\hline $\operatorname{ADG}(g / d)$ & $173.0^{\mathrm{b}}$ & $179.0^{\mathrm{a}}$ & $152.0^{c}$ & $162.0^{\mathrm{b}}$ & 6.01 & 0.0345 \\
\hline Total Gain (kg) & $18.1^{\mathrm{a}}$ & $18.7^{a}$ & $15.9^{\mathrm{b}}$ & $17.4^{\mathrm{b}}$ & 1.01 & 0.0345 \\
\hline $\mathrm{HCY}(\%)$ & $50.2^{\mathrm{a}}$ & $48.8^{\mathrm{a}}$ & $46.7^{b}$ & $48.6^{\mathrm{a}}$ & 1.22 & 0.0124 \\
\hline CCY (\%) & $46.3^{\mathrm{a}}$ & $45.0^{\mathrm{a}}$ & $42.9^{\mathrm{b}}$ & $45.1^{\mathrm{a}}$ & 1.21 & 0.0286 \\
\hline
\end{tabular}

Note: $\mathrm{BW}=$ body weight; $\mathrm{ADG}=$ average daily gain; $\mathrm{HCY}=$ hot carcass yield; $\mathrm{CCY}=$ cold carcass yield. Means in the same row with different superscripts differ significantly $(\mathrm{p}<0.05)$.

Table 3. Body size variables of lambs finished in Marandu pasture slaughtered at six months of age

\begin{tabular}{|c|c|c|c|c|c|c|}
\hline \multirow{2}{*}{ Variables } & \multicolumn{4}{|c|}{ Green-leaf offering (g/kg BW) } & \multirow{2}{*}{ SEM } & \multirow{2}{*}{$\mathrm{p}$} \\
\hline & 60 & 75 & 90 & 105 & & \\
\hline Body condition score (points) & 2.3 & 2.3 & 2.3 & 2.4 & 0.09 & 0.9564 \\
\hline Body length $(\mathrm{cm})$ & 85.9 & 83.4 & 83.1 & 85.6 & 1.11 & 0.1452 \\
\hline Chest girth (cm) & 86.2 & 83.8 & 86.7 & 87.4 & 23.85 & 0.5401 \\
\hline Rump height (cm) & 64.7 & 63.8 & 62.0 & 63.4 & 0.90 & 0.7552 \\
\hline Rump width (cm) & 25.4 & 25.8 & 24.8 & 25.8 & 0.29 & 0.5864 \\
\hline Chest width $(\mathrm{cm})$ & 22.6 & 23.0 & 23.0 & 22.9 & 0.32 & 0.9602 \\
\hline Height at withers $(\mathrm{cm})$ & 67.4 & 62.6 & 62.5 & 61.1 & 1.09 & 0.2374 \\
\hline
\end{tabular}

Note: BW= body weight. 
a significant effect of leaf offering on subcutaneous fat thickness (SFT). The lambs receiving $75 \mathrm{~g} / \mathrm{kg}$ offer showed the highest SFT $(5.8 \mathrm{~mm})$. There were no significant effects of treatments on cooking loss or shear force ( $>0.05$ ) (Table 4), which averaged $10.27 \mathrm{~kg}$ and $4.32 \mathrm{~kg}$, respectively. In the analysis of primal cuts, there was no significant difference for the weights of loin, leg, flank, neck, rib, rack, or shoulder among the green-leaf offerings $(60,75,90$, and $105 \mathrm{~g} / \mathrm{kg} \mathrm{BW})(\mathrm{p}>0.05)$ (Table 5).

\section{Economic Analysis}

The highest individual revenue per slaughtered lamb (US\$66.00) was obtained in lamb, receiving a green-leaf offering of $60 \mathrm{~g} / \mathrm{kg} \mathrm{BW}$. The best revenue per hectare (US\$ 563.00) was achieved with the treatment with a leaf offering of $75 \mathrm{~g} / \mathrm{kg} \mathrm{BW}$. The treatment with a leaf offering of $90 \mathrm{~g} / \mathrm{kg}$ BW resulted in the highest cost per hectare (US\$ 208.86), but which was similar to that obtained with the leaf offering of $75 \mathrm{~g} / \mathrm{kg} \mathrm{BW}$ (US\$
207.43). Lastly, the highest and best profit per hectare (US\$ 356.30) was obtained by the group treated with 75 g/kg BW (Table 6).

\section{DISCUSSION}

\section{Performance}

Because there were significant effects of leaf offer for final BW and average daily gain of lambs, being the highest results in lambs receiving $75 \mathrm{~g} / \mathrm{kg}$ of leaf-offer, this offer was able to meet the animal requirements just as well as the highest offering (105 g/kg BW) despite total and forage DMI were positively linear behavior and negatively linear for DMI of supplement, once the supplement was formulated according to NRC (2007), together with forage intake to meet a daily gain of 150 g/d. According to Silva (2016a), supplementation at the rate of $1.6 \% \mathrm{BW}$ for lambs on pasture is sufficient to minimize the negative effects of low herbage quality.

Table 4. Carcass characteristics and physical analysis of lambs finished on Marandu pasture slaughtered at 6 months old

\begin{tabular}{|c|c|c|c|c|c|c|}
\hline \multirow{2}{*}{ Variables } & \multicolumn{4}{|c|}{ Green-leaf offering (g/kg BW) } & \multirow{2}{*}{ SEM } & \multirow[b]{2}{*}{$\mathrm{p}$} \\
\hline & 60 & 75 & 90 & 105 & & \\
\hline HCW (kg) & 21.7 & 20.6 & 18.5 & 19.5 & 0.80 & 0.2141 \\
\hline CCW (kg) & 20.0 & 19.0 & 17.0 & 18.1 & 0.78 & 0.2869 \\
\hline SFT (mm) & $3.1^{\mathrm{b}}$ & $5.8^{\mathrm{a}}$ & $3.5^{\mathrm{b}}$ & $4.9^{\mathrm{a}}$ & 0.58 & 0.0184 \\
\hline LEA $\left(\mathrm{cm}^{2}\right)$ & 1.4 & 1.5 & 1.3 & 1.3 & 0.01 & 0.4172 \\
\hline $\mathrm{pH}$ & 5.8 & 5.8 & 5.9 & 5.7 & 0.05 & 0.7949 \\
\hline Internal length $(\mathrm{cm})$ & 63.0 & 61.9 & 61.0 & 62.1 & 0.69 & 0.5847 \\
\hline External length $(\mathrm{cm})$ & 90.9 & 93.8 & 95.5 & 86.5 & 2.81 & 0.8648 \\
\hline Leg length $(\mathrm{cm})$ & 40.7 & 38.2 & 37.9 & 38.1 & 0.62 & 0.1900 \\
\hline Chest depth $(\mathrm{cm})$ & 19.1 & 17.8 & 17.9 & 17.7 & 0.24 & 0.0869 \\
\hline Leg circumference (cm) & 41.4 & 40.9 & 39.1 & 40.7 & 0.60 & 0.4358 \\
\hline Muscle lightness & 37.5 & 38.0 & 38.9 & 39.7 & 0.44 & 0.0815 \\
\hline Ma & 15.8 & 15.2 & 15.5 & 15.0 & 0.22 & 0.4302 \\
\hline $\mathrm{Mb}$ & 9.6 & 8.0 & 8.3 & 9.8 & 0.65 & 0.8604 \\
\hline Fat lightness & 82.5 & 83.1 & 82.0 & 83.7 & 0.43 & 0.6384 \\
\hline $\mathrm{Fa}$ & 0.9 & 1.2 & 0.7 & 1.1 & 0.15 & 0.8789 \\
\hline $\mathrm{Fb}$ & 9.9 & 9.4 & 8.2 & 9.3 & 0.54 & 0.3474 \\
\hline Cooking loss (kg) & 12.5 & 10.6 & 9.2 & 8.8 & 0.77 & 0.2331 \\
\hline Shear force (kgf) & 3.6 & 3.3 & 3.7 & 3.4 & 9.09 & 0.1317 \\
\hline
\end{tabular}

Note: HCW= Hot carcass weight; $\mathrm{CCW}=$ Cold carcass weight; SFT= Subcutaneous fat thickness; LEA= Loin-eye area; Ma= muscle color ranging from green $(-)$ to red (+); $\mathrm{Mb}=$ muscle color ranging from blue $(-)$ to yellow (+); $\mathrm{Fa}=$ fat color ranging from green $(-)$ to red $(+) ; \mathrm{Fb}=$ fat color ranging from blue (-) to yellow (+); BW= body weight. Means in the same row with different superscripts differ significantly $(\mathrm{p}<0.05)$.

Table 5. Meat cuts of lambs finished on Marandu pasture slaughtered at 6 months old

\begin{tabular}{|c|c|c|c|c|c|c|}
\hline \multirow{2}{*}{ Variables } & \multicolumn{4}{|c|}{ Green-leaf offering (g/kg BW) } & \multirow{2}{*}{ SEM } & \multirow{2}{*}{$\mathrm{p}$} \\
\hline & 60 & 75 & 90 & 105 & & \\
\hline Loin (kg) & 0.8 & 0.7 & 0.7 & 0.7 & 0.17 & 0.8447 \\
\hline Leg (kg) & 3.3 & 3.1 & 2.8 & 3.0 & 0.78 & 0.5321 \\
\hline Flank (kg) & 0.5 & 0.5 & 0.5 & 0.5 & 0.12 & 0.2009 \\
\hline Neck (kg) & 0.8 & 0.7 & 0.7 & 0.7 & 0.18 & 0.9567 \\
\hline Rib (kg) & 1.4 & 1.3 & 1.2 & 1.2 & 0.32 & 0.0970 \\
\hline Rack (kg) & 1.4 & 1.3 & 1.1 & 1.2 & 0.32 & 0.3373 \\
\hline Shoulder (kg) & 1.9 & 1.8 & 1.7 & 1.7 & 0.44 & 0.7873 \\
\hline
\end{tabular}

Note: BW= body weight. 
Table 6. Revenues, expenses, and profits of lambs finished on Marandu pasture slaughtered at 6 months old

\begin{tabular}{|c|c|c|c|c|c|c|}
\hline \multirow{2}{*}{ Variables } & \multicolumn{4}{|c|}{ Green-leaf offering (g/kg BW) } & \multirow{2}{*}{ SEM } & \multirow{2}{*}{$\mathrm{p}$} \\
\hline & 60 & 75 & 90 & 105 & & \\
\hline Revenue (US\$/animal) & $66.0^{\mathrm{a}}$ & $62.6^{\mathrm{b}}$ & $56.0^{c}$ & $59.7^{b}$ & 0.91 & 0.032 \\
\hline Revenue (US\$/ha) & $318.6^{\mathrm{d}}$ & $563.7^{a}$ & $505.0^{\mathrm{b}}$ & $353.2^{c}$ & 0.36 & 0.005 \\
\hline Supplementation expenses (US\$) & $160.6^{\mathrm{b}}$ & $230.2^{\mathrm{a}}$ & $231.8^{\mathrm{a}}$ & $166.7^{\mathrm{b}}$ & 7.01 & 0.001 \\
\hline Individual expense (US\$/animal) & $12.3^{\mathrm{b}}$ & $14.4^{\mathrm{b}}$ & $17.8^{\mathrm{a}}$ & $10.4^{\mathrm{c}}$ & 0.75 & 0.001 \\
\hline Total profit (US\$) & $301.4^{\mathrm{b}}$ & $395.5^{\mathrm{a}}$ & $328.7^{b}$ & $251.5^{c}$ & 7.25 & 0.001 \\
\hline Individual profit (US\$/animal) & $23.2^{\mathrm{a}}$ & $24.7^{\mathrm{a}}$ & $25.3^{\mathrm{a}}$ & $15.7 \mathrm{~b}$ & 2.50 & 0.001 \\
\hline Area profit (US\$/ha) & $207.9^{c}$ & $356.3^{a}$ & $296.1^{b}$ & $208.3^{c}$ & 3.25 & 0.001 \\
\hline
\end{tabular}

Note: $\mathrm{BW}=$ body weight. Means in the same row with different superscripts differ significantly $(\mathrm{p}<0.05)$.

In this way, the animals manage to achieve satisfactory performance, which would be similar to that of feedlotfinished lambs.

Oliveira et al. (2016) stated in which the animals received 40,80 , or $120 \mathrm{~g} \mathrm{DM} / \mathrm{kg}$ of pasture, found a total weight gain of $16.85 \mathrm{~kg} / \mathrm{animal}$ during the same period of this research. This value is lower than the average of $18.7 \mathrm{~kg}$ per animal observed in the treatment of $75 \mathrm{~g} / \mathrm{kg}$ (Table 2), which shows that the performance of the production of supplemented animals can be affected when they receive varied pasture offers, as they fully meet nutritional requirements.

\section{Carcass Characteristics}

The similarity for most carcass measurements may be linked to the compensatory effect observed in food intake, and the animals that had higher leaf offerings showed less supplement intake and greater forage intake. In contrast, the animals that had less leaf supply consumed more supplements and less forage. This compensatory mechanism was not sufficient to level the nutrient intake, given the difference observed for the animals 'weight gain. However, the difference of three $\mathrm{kg}$ in the animals' final weight was not enough to change the weight and carcass and commercial cuts.

In commercial terms, the producer is mostly concerned with hot carcass yield (HCY), calculated as HCW divided by slaughter weight (Rezende et al., 2019). In the present study, the average carcass yield was $48.3 \%$, higher than the $38.9 \%$ found by Trindade et al., (2018) in Santa Ines sheep finished in tropical pastures receiving supplementation at a rate of $1.38 \%$ of body weight. Several factors may have contributed to these results, from the management of rearing, weight, and age of weaning to the type of pasture used, sex, and mainly, quantity, and quality of pasture offered to the finishing lambs.

Oliveira et al. (2016) analyzed the performance and carcass characteristics of mixed-breed sheep raised on pastures of two Buffel-grass cultivars, under varied herbage offerings $(40,80$, and $120 \mathrm{~g}$ total $\mathrm{DM} / \mathrm{kg} \mathrm{BW})$, and found respective HCW values of 18.62, 16.52, and $17.19 \mathrm{~kg}$, which were lower than the average of $20.07 \mathrm{~kg}$ obtained by all treatments in the present experiment. It can be understood that these differences are due to the quality of herbage offered to the animals, since the quantity supplied was similar, on average. The minimum SFT to protect the carcass during chilling is $1.4 \mathrm{~mm}$ (Pearce et al., 2017). The average SFT observed in the treatments with herbage offerings of $60,75,90$, and $105 \mathrm{~g} / \mathrm{kg} \mathrm{BW}$ in the present study were 3.07, 5.79, 3.52 , and $4.91 \mathrm{~mm}$, respectively, which meet the criteria for protection. Silva (2016b) supplemented lambs on pasture during the finishing stage at the rate of $1.6 \%$ BW and observed a fat thickness of $1.6 \mathrm{~mm}$ in the carcass. Oliveira et al. (2017) finished ewes in a feedlot and obtained a respective FTS value of $1.56 \mathrm{~mm}$, the value that was much lower than those described in Table 4 . Therefore, it is believed that supplementation is maintained at $1.6 \%$ of body weight; it was favorable to the fat of the animals under varied forage offerings. In addition, the fact that the animals were fed fluently during the pre-weaning phase may explain these high values of FTS, which a pasture-only regime would not be allowed.

Supplementation emerges in this scenario as a mean of meeting the lamb's nutritional requirements, besides directly contributing to the finishing process for slaughter. Souza et al. (2010) evaluated different supplementation levels for grazing sheep $(0,0.6,1.3$, and $2.0 \% \mathrm{BW}$ ) and found that increasing supplementation levels led to the increases in external carcass length, rump width, chest depth, rump circumference, and leg circumference. However, even more important than supplementation is an adequate herbage offering. We found no difference among leaf-offering in in vivo pre-slaughter analysis of lambs finished on Marandu pasture slaughtered at 6 months old receiving supplementation of $1.6 \% \mathrm{BW}$.

The rib eye area was an average of $13.85 \mathrm{~cm}^{2}$, higher than the $11.95 \mathrm{~cm}^{2}$ reported by Silva (2016b) in sheep supplemented with $1.6 \% \mathrm{BW}$ in pastures of Urochloa spp. The present results are also higher than the 9.03 $\mathrm{cm}^{2}$ found by Urbano et al. (2015) in sheep finished in confinement, both works were developed in experimental periods similar to this work. These differences are probably due to varying body size, body weight, and age at slaughter. The average slaughter weight in the present study was $41.5 \mathrm{~kg}$, while Urbano et al. (2015) found an average of $29.5 \mathrm{~kg}$.

As stated by Ítavo et al. (2019) and Silva et al. (2019), fat was the carcass component that most varied in terms of thickness, color, flavor, and quantity. In this regard, Osório et al. (2012) described the importance of fat for meat, as it gave flavor and aroma and protected it during the chilling period. Despite these assertions, 
there were no significant differences in the color of fat or muscle between the leaf-offering tested in the present study.

\section{Meat Quality}

No significant differences were observed for primal cuts, which may be because the animals received the same type of herbage and supplement, extracting the ideal amount of nutrients from them. In doing so, they met their requirements and achieved optimum body conditions.

Physical characteristics of meat, such as tenderness, color, and lightness, are important attributes at the time of purchase (Gois et al., 2017). In the present study, these variables did not show significant differences, because, regardless of the amount of forage or supplement consumed, the finishing system was the same. The feeding and finishing systems to which the sheep are subjected can alter the quality of their meats (Silva et al., 2019 Ítavo et al., 2019). The shear force was $3.5 \mathrm{kgf}$, presenting an aspect of intermediate mercies (Costa et al., 2018). Costa et al. (2018) obtained $7.52 \mathrm{~kg} / \mathrm{cm}^{2}$ in supplemented grazing sheep. This better softness value in this research may be due to the animal breed and, mainly, to the age of slaughtering. Younger animals of meat breeds produce softer meat when compared to animals of mixed breeds, such as those used in the present study.

The $\mathrm{pH}$ of meat (5.59) did not differ between the leaf offering treatments. This result suggests that the finishing system does not interfere with the quality of the final product, considering that all animals consumed the same type of herbage and received the same amount of supplement $(1.6 \% \mathrm{BW})$. Similar findings were reported by Silva (2016b) (average $\mathrm{pH}: 5.74$ ) and Costa et al. (2018) (average pH: 5.85), in experiments with grazing lambs.

\section{Economic Analysis}

The highest profit per slaughtered animal was achieved between the leaf-offerings of $60 \mathrm{~g} / \mathrm{kg}$ BW, while the highest profit per hectare was obtained in the treatment with leaf offering of $75 \mathrm{~g} \mathrm{DM} / \mathrm{kg}$ BW. Therefore, despite the lack of significant differences $(p>0.05)$ for in vivo measurements, carcass characteristics, and meat quality variables in lambs finished on Marandu pasture and receiving supplementation at $1.6 \% \mathrm{BW}$, the profit can be an extremely important factor of great interest to sheep producers and consumers. We observed better profits (total, individual, and by area) in leaf offering of $75 \mathrm{~g} \mathrm{DM} / \mathrm{kg}$ BW.

\section{CONCLUSION}

We recommend $75 \mathrm{~g} / \mathrm{kg}$ of $\mathrm{BW}$ of leaf offering of Marandu pasture for finishing lambs when aiming at the increased performance and total profit without alterations in carcass characteristics, or meat characteristics.

\section{CONFLICT OF INTEREST}

We certify that there is no conflict of interest with any financial, personal, or other relationships with other people or organizations related to the material discussed in the manuscript.

\section{ACKNOWLEDGEMENT}

The authors thank to Federal University of Mato Grosso do Sul, to Conselho Nacional de Desenvolvimento Científico e Tecnológico, and to Fundação de Apoio ao Desenvolvimento do Ensino, Ciência e Tecnologia do Estado de Mato Grosso do Sul for financial support; and carried out with the support of the Coordenação de Aperfeiçoamento de Pessoal de Nível Superior - CAPES (Financing Code 001).

\section{REFERENCES}

AOAC. 2000. Official methods of analysis of AOAC International. $16^{\text {th }}$ ed. Association of Official Analytical Chemists, Arlington

Araújo Filho, J. T., R. G. Costa, A. B. Fraga, W. H. Sousa, M. F. Cezar, \& A. S. M. Batista. 2010. Desempenho e composição da carcaça de cordeiros deslanados terminados em confinamento com diferentes dietas. R. Bras. Zootec. 39: 363-371. https://doi.org/10.1590/S1516-35982010000200020

Costa, H. H. A., E. O. S. Saliba, D. B. Galvani, A. V. Landim, L. D. Lima2, A. L. C. C. Borges, M. A. D. Bomfim, I. Borges, \& F. A. Silva. 2018. Efeito da suplementação com sulfato de zinco ou propilenoglicol em ovinos em uma pastagem nativa da Caatinga no período chuvoso: desempenho, características da carcaça e da carne. Arq. Bras. Med. Vet. Zootec. 70: 993-1003. https://doi.org/10.1590/1678-4162-8998

Costa, M. C. M., L. C. V. Ítavo, C. C. B. F. Ítavo, A. M. Dias, H. Petit, F. A. Reis, R. C. Gomes, E. S. Leal, M. V. G. Niwa, \& G. J. Moraes. 2019. Evaluation of internal and external markers to estimate faecal output and feed intake in sheep fed fresh forage. Anim. Produc. Sci. 59:741-748. https://doi. org/10.1071/AN16567

Euclides, V. P. B., D. B. Montagner, M. C. M. Macedo, A. R. Araújo, G. S. Difante, \& R. A. Barbosa. 2019. Grazing intensity affects forage accumulation and persistence of Marandu palisadegrass in the Brazilian savannah. Grass. Forage. Sci. 75:1-13. https://doi.org/10.1111/gfs.12422

Euclides, V. P. B., P. C. Costa, K. Euclides Filho D. B. Montagner, \& G. R Figueiredo. 2018. Biological and economic performance of animal genetic groups under different diets. Biosci. J. 34:1683-1692. https://doi.org/10.14393/ BJ-v34n6a2018-39808

Goering, H. K. \& P. J. Van Soest. 1970. Forage Fiber Analysis (apparatus, reagents, procedures and some applications), USDA Agricultural Handbook. 379:20.

Gois, G. C., E. M. Santos, W. H. Sousa, J. P. F. Ramos, P. S. Azevedo, J. S. Oliveira, G. A. Pereira, \& A. F. Perazzo. 2017. Qualidade da carne de ovinos terminados em confinamento com dietas com silagens de diferentes cultivares de sorgo. Arq. Bras. Med. Vet. Zootec. 69: 1653-1659. https://doi.org/10.1590/1678-4162-9231

Gordon, H. Mc. L. \& H. V. Whitlock. 1939. A new technique for counting nematode eggs in sheep faeces. J. Counc. Scient. Indust Res. 1939; 12: 50-52.

Ítavo, C. C. B. F., L. C. V. Ítavo, C. A. T. Esteves, G. A. Sapaterro, J. A. Silva, P. C. G. Silva, K. L. S. M. Ferelli, \& T. F. F. S. Arco. 2019. Influence of solid residue from alcoholic extraction of brown propolis on intake, digestibility, 
performance, carcass and meat characteristics of lambs in feedlot. J. Anim. Feed Sci. 28:149-158. https://doi. org/10.22358/jafs/109284/2019

Lippke, H. 2002. Estimation of forage intake by ruminants on pasture. Crop Sci. 42, 869-872. https://doi.org/10.2135/ cropsci2002.8690

McDougall, E. I. 1948. Studies on ruminant saliva. 1. The composition and output of sheep's saliva. J Bioch. 43:99-109. https://doi.org/10.1042/bj0430099

NRC (National Research Council). 2007. Nutrient requirements of small ruminants $2^{\text {th }}$ Rev. Ed. National Academy Press, Washington DC

Oliveira, J. P. F., M. A. Ferreira, A. P. D. Freitas, S. A. Urbano, \& Á. E. M. Silva. 2017. Carcass characteristics in Santa Inês sheep fed with mazoferm as a substitution for soybean meal. Rev. Ciênc. Agron. 48: 708-715. https://doi. org/10.5935/1806-6690.20170082

Oliveira, R. G., T. V. Voltolini, C. Mistura, A. S. Moraes, R. A. Souza, \& B. R. C. Santos. 2016. Productive performance and carcass characteristics of lambs grazing on pastures of two cultivars of Buffel grass and three forage allowance. Rev. Bras. Saúde Prod. An. 17:374-384. https://doi. org/10.1590/S1519-99402016000300005

Osório J. C., M. N. Oliveira, P. O. Jardim, \& E. M. Monteiro. 1996a. Meat production in sheep of five genotypes. 2. Live weight components. Cienc. Rural. 26:471-475. https://doi. org/10.1590/S0103-84781996000300023

Osório, J. C., N. M. Oliveira, A. P. Nunes, \& J. L. Pouey. 1996b. Meat production in sheep of five genotypes. 3. Losses and morphology. Cienc. Rural. 26:477-481. https://doi. org/10.1590/S0103-84781996000300024

Osório, J. C. S., M. T. M. Osório, F. M. Vargas Junior, A. R. M. Fernandes, L. O. Seno, H. A. Ricardo, F. C. Rossi, \& M. A. P. Orrico Junior. 2012. Criteria for animal slaughter and the meat quality. Rev. Agrarian. 5:433-443. http://ojs.ufgd. edu.br/index.php/agrarian/article/view/1822

Pearce, K. L., K. Rosenvold, H. J. Andersen, \& D. L. Hopkins. 2011. Water distribution and mobility in meat during the conversion of muscle to meat and ageing and the impacts on fresh meat quality attributes - A review. Meat Sci. 89: 111-124. https://doi.org/10.1016/j.meatsci.2011.04.007

Rezende, P. L. P., J. Restle, U. O. Bilego, J. J. R. Fernandes, R. L. Missio, \& T. P. Guimarães. 2019. Carcass characteristics of feedlot-finished Nellore heifers slaughtered at different weights. Acta Sci. Anim. Sci. 41: e44826. https://doi. org/10.4025/actascianimsci.v41i1.44826
RIISPOA. 'Regulamento da Inspeção Industrial e Sanitária de Produtos de Origem Animal'. 1997. Brasília-DF: Ministério da Agricultura. p.35.

Russel, A. J. F., J. M. Doney, \& R. G. Gunn. 1969. Subjective assessment of body fat in live sheep. J. Agric. Sci. 72:451-454. https://doi.org/10.1017/S0021859600024874

Silva, J. A. 2016a. Produção de cordeiros em diferentes sistemas de cria e terminação em pastagens de Urochloa spp. Tese (Doutorado) - Faculdade de Medicina Veterinária e Zootecnia, Universidade Federal de Mato Grosso do Sul, Campo Grande, MS. Brazil.

Silva, P. C. G. 2016b. Características de carcaça e carne de cordeiros produzidos em diferentes sistemas de terminação. Tese (Doutorado) - Faculdade de Medicina Veterinária e Zootecnia, Universidade Federal de Mato Grosso do Sul, Campo Grande, MS. Brazil.

Silva, J. A., C. C. B. F. Ítavo, L. C. V. Ítavo, M. G. Morais, P. C. G. Silva, K. L. S. M. Ferelli, \& T. F. F. S. Arco. 2019. Dietary addition of crude form or ethanol extract of brown propolis as nutritional additive on behaviour, productive performance and carcass traits of lambs in feedlot. J. Anim. Feed Sci. 28: 31-40. https://doi.org/10.22358/jafs/105442/2019

Souza, R. A., T. V. Voltolini, L. G. R. Pereira, S. A. Moraes, D. B. Manera, \& G. G. L. Araújo. 2010. Productive performance and carcass traits of lambs grazing on irrigated pastures and receiving increasing concentrate levels. Acta Sci Anim Sci. 32:323-329. https://doi.org/10.4025/actascianimsci.v32i3.8320

Tilley, J. M. A. \& R. A. Terry. 1963. A two stage technique for the in vitro digestion of forage crops. J. British. Grassl. Society. 18:104-111. https://doi.org/10.1111/j.1365-2494.1963. tb00335.x

Trindade, T. F. M., G. S. Difante, J. V. Emerenciano Neto, L. S. Fernandes, I. M. M. Araújo, E. L. L. Véras, M. G. Costa, M. G. T. Silva, \& M. C. Medeiros. 2018. Biometry and carcass characteristics of lambs supplemented in tropical grass pastures during the dry season. Biosci. J. 34: 172-179. https://doi.org/10.14393/BJ-v34n1a2018-36781

Urbano, S. A., M. A., Ferreira, R. M. L. Véras, P. S. Azevedo, H. B. Santos Filho, G. A. Vasconcelos, \& J. P. O. Oliveira. 2015. Características de carcaça e composição tecidual de ovinos Santa Inês alimentados com manipueira. Ver. Bras. Ciênc. Agrar. 10: 466-472. https://doi.org/10.5039/agraria. v10i3a4812 